\title{
Cross-Ethnic Society and Social Integration
}

\author{
Monica Tiara ${ }^{(1)}$ Maria Montessori ${ }^{(2)}$, Fatmariza $^{(3)}$ Junaidi Indrawadi ${ }^{4)}$ \\ (1) (2)(3)(4) Universitas Negeri PadangDepartment of Pancasila and Civic Education monicatiara \\ Corresponding Author: Monica Tiara
}

\begin{abstract}
This article aimed to reveal the dynamics of inter-ethnic society in the District of West Padang at Padang City which has a distinctive pattern in anticipation of inter-ethnic conflicts and disintegration. By using the descriptive analysis, the data collected from observation, interviews and documentation study, formulated several important findings. First, acculturation between the values of religion and culture in the form of the value of tolerance and brotherhood are important elements which become elements forming social integration between ethnic Chinese and ethnic Minangkabau Muslim. Second, the process of social integration in the ethnic Chinese community and ethnic Minangkabau Muslim has awakened from generation to generation within the common housing that is supported by a commitment to make the variation with the local culture.
\end{abstract}

Keywords: Social Integration, Ethnic, Chinese Muslims, Minangkabau

Date of Submission: 28-05-2018

Date of acceptance: 11-06-2018

\section{INTRODUCTION}

Indonesia is one of the characteristics of the archipelago with diverse nation in the world. This reflects that Indonesia is a country that is multiethnic and multicultural. As a multi-ethnic state, Indonesia have ethnically diverse local and ethnic immigrants. The diversity if not managed, it tend to create conflicts. The conflicts tend to arise because each ethnicity has a view and a different identity. Therefore, there is a need for adjustments to ensure the social integration in the community, especially people across ethnicity.

Adjustment of inter-ethnic society can be built through a process of social integration. Social integration in a multiethnic society can be done in the form of understanding of multiculturalism (Eka Hendri: 2013). in the form of social integration, it will need a willingness to accept differences. So that a feeling of alienation does not appear to be a principle in the dynamics of inter-ethnic society. So that each ethnic group can identify other ethnic groups as a form of suppressive potential inter-ethnic conflict in society.

This condition indicates that the sharp difference in the cross-ethnic society to be sensitive if it concerns the difference of identity and trust. As in studies conducted by Liliweri (2005) revealed that the identity is a strong boundaries to evaluate the presence of a group to another group.

Different from what happened in Padang, inter-ethnic social integration, especially ethnic Chinese and ethnic Minangkabau has been going on for a long time without losing its identity. Erniwati (2011) in his research has revealed that ethnic Chinese have built a social integration with ethnic Minangkabau since the colonial period through trade.

Social integration in communities across ethnicity in Padang become an interesting study because each ethnic have managed to maintain their culture without becoming strangers to each other within the framework of Islam. Religion in this case be able to create a religious norm adhesive inter-ethnic public relations without eliminating Characteristic of each ethnic. Social integration between ethnic Chinese and ethnic Minangkabau are supported with values typical style of brotherhood and tolerance of Islam becomes an important element.

Abdullah Idi (2012: 361-383) stated that highlights one of the cult and experience across ethnic and social harmony among religions namely Malay-Bangka-Islam with the ethnic Chinese population. In the results showed that the harmony of the long-running and walking naturally without the "engineering" social systematically. That fact supports Indonesiaan framed in unity. Furthermore, Tri Joko (2013) in his research also revealed that the presence of Arabs in the village of Ampel Surabaya to integrate with the native population, especially Javanese and Madurese with a background in the Islamic religion, local people tend to accept the existence of ethnic Arabs are well supported by the government's commitment,

Based on the results of previous studies above can be understood that the trust can be the buildingblocks of social integration. While this article reveal social integration as a result of religious and cultural acculturation that has been realized in inter-ethnic social reality. Therefore, this study specifically discuss how culture and religion become inseparable unity of values in society and ethnic Muslim Chinese ethnic Minangkabau without losing its original identity. 


\section{RESEARCH METHOD}

This article was analyzed using a qualitative approach to the type of research Based on the study of the problem and focus research on social integration and the prevention of conflict the ethnic Chinese community (Muslim and non-Muslim) ethnic Minagkabau research is conducted through a qualitative approach, to get the in-depth study and holistic. This is suitable with the opinion from Sudjana (2008: 72) that states the qualitative research is a form of research that indicated to describe or depict phenomena that exist, whether the phenomenon of events, social activities, attitudes, beliefs, perceptions, thoughts of people individually and groups that are natural or human engineering. Therefore, qualitative research in this case intended to explore the meaning behind the behavior of human action, in qualitative research the researcher as the main instrument of data collection. The involvement of researchers in the data collection process will produce research that can be justified. Therefore qualitative methods considered appropriate for public research on cross ethnicity. In this case, the use of qualitative methods is more appropriately used for revealing all phenomena are real and comprehensive as the process of social integration between Muslims and ethnic Chinese ethnic Minangkabau in Padang.

\section{RESULTS AND DISCUSSION}

Kampung Pondok Padang is administratively located in the district of West Padang. In addition the area is also known as "Kampuang Cino", because most of the people are ethnic Chinese. Other ethnic inhabiting this region are ethnic Minangkabau, Arabic, Indian, Javanese, Batak etc with diverse composition. Atmosphere settlements in this area differs from other areas in the city of Padang. Chinese culture into its own characteristics in the arrangement to the architecture without leaving the local culture (Minangkabau). A typical residential atmosphere indicate that the Chinese ethnic community has been part of Padang. As disclosed in Erniwati study (2011) that the ethnic Chinese in the city of Padang has existed since the 13th century to trade with the Minangkabau ethnic. This indicates that the similarity settlement a factor supporting the awakening of social integration in inter-ethnic society, especially the Chinese ethnic community with minangnese

As a foreign descent, the Chinese ethnic community in the village cottage village still retains its original culture in the middle of the Moslem-majority population. Not hayal majority Chinese ethnic community to convert to Islam. Factors history up inter-ethnic dynamics of the community impact on the improvement of confidence in each of the Chinese ethnic ethnicity without exception in Padang. Transformation of the Chinese ethnic communities become Muslims a great influence in the process of assimilation with the local ethnic (Minangkabau). Islamic religious reference in the paradigm and behavior of the Chinese ethnic communities and ethnic Minang in Padang.

The similarity of belief become a link in the Chinese ethnic assimilation and ethnic Minangkabau. Adherent of Islam holds the concept ukuwah where this concept suggests that anyone who is the brother and sisters. The concept provides every entanglement adherents regardless of "who". Can be understood that an essential element in social integration between the ethnic Chinese community and Minangkabau Muslim faith is the bond of brotherhood.

The concept of the Brotherhood of the faith have an impact on the public mindset and ethnic Muslim Chinese ethnic same minangkabau giving rise to values that can be used together. The value is a sense of mutual acceptance and understanding. A sense of mutual acceptance and understanding led to the development of the concept of Islam as rahmatan Lil Alamin in Paradigm Muslim ethnic Chinese and ethnic Minangkabau resulting in building inter-ethnic social integration would promote tolerance as forming elements of social integration irrespective of ethnicity flavor. This is in line with research Monica (2018) which revealed that tolerance builds social integration will foster hope and cooperation into new experiences among each ethnic. So that inter-ethnic society will strive to maintain good relations for the creation of social integration is intact.

Another element which becomes binding relationship between the community and the Muslim Chinese ethnic Minangkabau society is characteristic of Minangkabau culture that is synonymous with Muslim and ethnic Minangkabau ability to accept new things. On the other hand, the ability of Chinese ethnic Padang in maintaining their identity from generation to generation without having to "impose its will" become a key public relations in inter-ethnic harmony. Socio-cultural implications that occur in the cross-ethnic society in the cottage village tends to produce cultural acculturation without losing the identity of each ethnic. A sense of mutual acceptance and mutual understanding are summarized in the values of brotherhood and sisters who became the concept of peace and the need for cross-ethnic society in achieving social integration is intact. The taste is embodied variously by ethnic Muslim Chinese ethnic Minangkabau.

\section{CONCLUSION}

Based on the results of the research and discussion shows that there are three patterns of integration that is built in social interaction in the community of Kampung Pondok district in WestPadang, namely pattern faithfulfraternal relations, it is very visible from Muslim Chinese ethnic relationship with the Minangkabau 
ethnic Muslim majority. Their interaction is very strong, especially in religious activities; they are able to keep their interactions regardless of their ethnicity and culture respectively. Understanding that Islam is rahmatan lil Alamin be a strong adhesive interaction awakened.

\section{REFERENCES}

[1]. Abdullah Idi. 2012. "Harmoni Sosial: Interaksi Sosial "Natural-Asimilatif”antara Etnis Muslim Tionghoa dan Melayu-Bangka". Fakultas Tarbiyah IAIN Raden Fatah Palembang. ThaqÃfiyyÃT, Vol. 13, No. 2, Desember 2012

[2]. Eka Hendri Ar. Dkk. 2013. Integrasi Sosial dalam Masyarakat Multietnik. STAIN Politeknik. Jurnal Wali Songo, Vol. 21, No. 1. Mei 2013. Hal. 194

[3]. Erniwati. 2011. China Padang dalam Dinamika Masyarakat Minangkabau: dari Revolusi Sampai Reformasi. Jakarta: Universitas Indonesia.

[4]. Liliweri, Alo. 2005. PrasangkadanKonflik. LKIS.Yogyakarta.

[5]. Monica Tiara. 2018. "Integrasi Sosial Etnis Tionghoa Non Muslim dan Etnis Tionghoa Muslim dengan Etnis Minangkabau di Kecamatan Padang Selatan Kota Padang” Universitas Negeri Padang.

[6]. Sudjana, Nana. 2010. Penelitiandan Penilaian Pendidikan. Bandung: Sinar Baru Algensido

[7]. Tri Joko Sri Haryono. 2013. Integrasi Etnis Arab dengan Jawa dan Madura di Kampung Ampel Surabaya. Antropologi FISIP- Universitas Airlangga, Surabaya. BioKultur, Vol.II/No.1/Januari-Juni 2013, hal. 13 .

IOSR Journal Of Humanities And Social Science (IOSR-JHSS) is UGC approved Journal with S1. No. 5070, Journal no. 49323.

Monica Tiara "Cross-Ethnic Society and Social Integration." IOSR Journal Of Humanities And Social Science (IOSR-JHSS). vol. 23 no. 06, 2018, pp. 58-60. 